Mikhail Maizuls

\title{
The Punishment of Saints as Pious Blasphemy in the Middle Ages and Early Modern Period
}

Translation by Isaac Wheeler

DOI: 10.22394/2311-3448-2017-4-2-25-57

Mikhail Maizuls - Independent Researcher. maizuls@gmail.com

This article is devoted to the wide set of practices of coercion and punishment of saints via their images that are well documented in the Catholic world from the early Middle Ages to the Early Modern period. According to the basic historiographical narrative, the humiliation of saints officially practiced by medieval monks and canons was prohibited by the Second Council of Lyon in 1274, leading to the gradual marginalization of this devotional "instrument." Nevertheless, exempla that presented the coercion of saints as a legitimate (although radical) method of communication with supernatural powers continued to appear in collections for preachers even in the Counter-Reformation period. At the same time, by the late Middle Ages and the Early Modern period, these practices had been gradually reinterpreted as superstition and/or blasphemy (sacrilege). This transformation is due to two interdependent agendas: the growing delegitimization and even demonization of popular religion by Church intellectuals and prelates, and the Protestant iconoclasm of the 16th and 17th centuries, which made the ecclesiastical authorities, who were anxious to protect the core of the traditional faith, much more sensitive to any form of irreverence or deviance toward statues or other images of saints.

Keywords: cult of images, blasphemy, sacrilege, iconoclasm, hagiography, exempla, canon law, Second Council of Lyon, Council of Trent. 
$\mathrm{I}$ $\mathrm{N}$ his memoirs, the Spanish director Luis Buñuel recalled rumors spreading through Madrid in 1936, following the start of the Civil War, to the effect that the mother superior of a certain monastery had used a hammer and chisel to chip the figure of Jesus off their statue of the Virgin Mary, and declared to the Queen of Heaven that she would only return him when "we [the nationalists - M. M.] win the war” (Buñuel 1985; Bel'ting 2002).

As Clausewitz famously put it, war is the continuation of politics by other means. In precisely the same way, violence against sacred objects sometimes serves as a radical form of prayer; communion with higher powers sometimes leads to raised voices. Before attacking a Polish castle in Lyakhavichy in 166o, Russian voivode Ivan Khovansky hoisted an icon of Saint Nicholas the Wonderworker up onto his shoulder. When the assault failed, however, he ordered that it be slashed "into splinters" with a whip (Bulychev 2005). In 1690, thirty years later and on the other side of the world, a woman in the Mexican town of Cocula lost a Chinese porcelain cup. Terribly angry, she threw a statue of the Virgin Mary to the floor, called her an "Indian harlot," and threatened to leave her there if she did not return the lost object (Gruzinski 1994).

Neither the Orthodox voivode nor the Catholic lady from a colonial town was an iconoclast, and it is unlikely that they believed they were engaging in some form of blasphemy or sacrilege. They had put their faith in the intercession of Saint Nicholas and the Virgin Mary, only to be let down, betrayed, and left to their plight. In ordering that the icon be broken or throwing a statuette on the floor, they, unlike their Protestant contemporaries or (non-)religious freethinkers, were not denying the power of those images, but were rather appealing to that power through violence; they were punishing the higher powers for abandoning them in their time of need, and/or were attempting to coerce them to come to their aid.

It is obvious that punishment/blackmail directed toward saints through their images (and sometimes through their relics) in the Catholic world of the Late Middle Ages and Early Modern Period was a relatively widespread practice, not just an unusual deviation. ${ }^{1}$ It had

1. The inquisitorial archives of colonial Mexico in the sixteenth and seventeenth centuries have preserved the majority of cases dealing with routine violence against images of saints. Some of them were associated with punishment or blackmail. As the French historian Serge Gruzinski notes, images "were threatened and blackmailed, as if they could be forced to meet the demands of their owner. . . They were also insulted, flogged, scratched, slapped, burned with a candle, broken, torn, stamped on, 
a collective dimension as well as an individual one. In the individual dimension, someone in a fit of rage against the higher powers settles the score with images, whether they belong to him or they are kept in a Church and he simply regards them with special reverence. In the collective dimension, punishment or blackmail directed against saints translates into group action, which is often ritualistic in nature, intended to avert some sort of general misfortune; for example, during a drought, the faithful rushed to the riverbank and threw in a statue of their patron saint. While the resident of Cocula decided to retaliate against the Virgin Mary over a broken cup, the Catholic hierarchy and Church intellectuals unequivocally classified punishment/blackmail directed against saints as impermissible.

Several centuries before, however, monks and canons engaged in similar practices with full official sanction, and the "books of miracles" (libri miraculorum) compiled at various pilgrimage sites included miracles performed by local saints (or images of them) in response to blackmail. Furthermore, these were not miracles associated with punishment, which are so common in accounts of church robbers and iconoclasts, but rather "positive miracles," a gracious reply to the supplicant's "forceful" prayer. As is well known, ritualistic humiliation of relics and images was officially banned in 1274 at the Second Council of Lyon. It is obvious, however, that this decision, which involved only one type of practice and only applied to the clergy, did not put an end to the story of punishment/blackmail directed against heavenly patrons.

In the last years of the seventeenth century, soon after the revocation of the Edict of Nantes, which had granted a range of freedoms to the Protestant minority of France, an illustrated pamphlet exposing the vices of Catholic monks was published in Amsterdam. One of the most prominent monks in this satirical gallery of gluttons, drunkards, fornicators, crooks, and money-grubbers is a certain "Portuguese father." In the engraving, a monstrous Franciscan monk lashes a statue of Saint Anthony of Padua with a whip, demanding that he perform a miracle (fig. 1).

stabbed, pierced, cut into strips with scissors, tied to horses' tails and covered with red paint or even human excrement (Gruzinski 1995, 67-68). See also Corteguera 2016. 


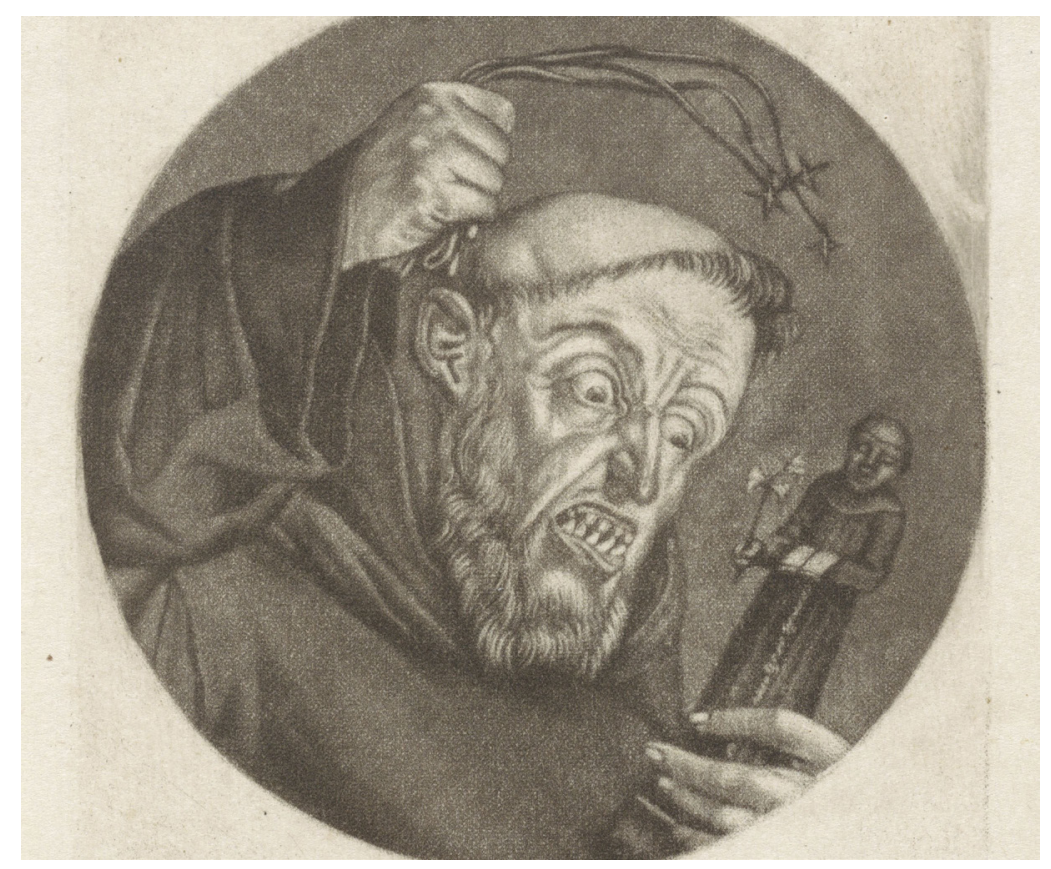

Fig. 1. A Franciscan monk beats a statue of Saint Anthony of Padua (Renversement de la morale chrétienne par les désordres du monachisme. 2e partie. Amsterdam, 1695).

In this article, I will trace how various practices of punishing/ blackmailing religious images were legitimized in the eleventh to thirteenth centuries, how they were later officially reclassified as superstition and/or sacrilege (blasphemy), and how violence toward sacred images could serve diametrically opposed goals.

\section{Legitimate Abuse}

Patrick Geary noted that the ritualistic humiliation of relics and sacred images was officially incorporated into the liturgical practice of many monasteries and communities of canons in the eleventh to thirteenth centuries (Geary 1979; cf. Little 1979; Schmitt 2005). They most often resorted to this measure during the course of conflicts with secular seigneurs who were encroaching on Church lands or attempting to put pressure on the clergy in other ways. When the confrontation reached an impasse and there were no other forms of resistance available, the brothers would denounce the wrongdoer during the mass and call 
out to God for intercession (a "clamor"). In addition to their invocations, the clerics would sometimes take reliquaries, crucifixes, statues of saints and the Gospels down from the altar. They would them lay them on the floor and cover them with thorns (they would do the same to the altar, saints' graves, etc.). A similar ritual of humiliation could also be built into the mass or unfold separately, though it would still be part of the religious service. In some cases, the holy items would be returned to their places after the clamor was concluded; in others, they would be left where they were until the brothers got what they wanted. ${ }^{2}$ In the latter case, the monks or canons would stop performing religious services and deny laypeople access to the relics or barricade the entrance to the church entirely.

These measures were regulated by liturgical rules and compilations of "customs" (consuetudines) of particular communities, and were intended to put pressure on both the wrongdoer himself and the patron saint. The former, because the brothers, by halting services and announcing their humiliation to all, compelled him to reconsider and ultimately give in. The latter, since he had left his children without aid and therefore had to experience the same humiliation to which the brothers had been condemned. Although the liturgical texts did not say so directly, such measures were intended to prompt and coerce heavenly protectors to intervene, to awaken their power.

Obviously, the threat that the saints would lose the honor appropriate to them was used as a way to get something out of them long before the era Geary described. For example, in the sixth century, Gregory of Tours's book Glory of the Confessors (chapter 70, “The Confessor Mitrias of Aix") described how a certain Childeric, an important figure in the court of King Sigebert, took a villa in Aix away from the Church. The local bishop, Franco, went to the tomb of Saint Mitrias, said his prayers and then threatened him: "Most glorious saint, no more lights will be lit here, no more melodies of psalms will be sung, until you first avenge your servants from their enemies and restore to the holy church the properties that have been violently taken from you." The bishop went on to cover the grave with thorns and bar the doors of the church. The wrongdoer fell ill soon after, spent a year in

2. For example, in the mid-eleventh century, the monks of the abbey of St. Medard in Soissons entered into a conflict with Duke Gothelo of Lotharingia, since King Henry I had transferred the village of Donchery to him, despite the fact that the monks regarded it as theirs. In order to win the duke over, they kept the reliquary of their patron saint on the floor of the church for an entire year until he reconsidered (Geary 1979, 39). 
torment and realizing his guilt, commanded that the villa be returned to the Church, along with 600 gold coins; nonetheless, he drew his last breath soon after (Monumenta Germaniae Historica 1885, 339; Van Dam 2004, 51).

The question of the legitimacy of these practices was raised at the Thirteenth Council of Toledo, held in Visigothic Spain in 683. They condemned clerics and other churchmen who would grow so angry and resentful toward someone that they dared to rip the cloths from altars and cover them with funeral cloth instead, put out candles, and halt services. If they did not receive forgiveness from the clerics above them in the hierarchy, they were meant to be stripped of their offices for this offense. This ban, however, was softened by a significant exception. In justifiable circumstances, when the clerics resorted to these methods in order to oppose their enemies or stave off a threat to the faith, their actions were driven by humility rather than impudence, and were therefore acceptable (Mansi 1765, 1069-70).

Naturally, in the West, this Early Medieval practice of reverential threats was, as a rule, directed toward the relics of saints rather than images of them. It was the relics that constituted the presence of heavenly patrons in this world and served as the main conduits of their power (virtus). It was only after 1000, or, depending on the dating system, the late twelfth to thirteenth century, after two- and three-dimensional images broadly acquired the status of repositories of virtus and also began to play the role of intermediaries between man and higher powers, that believers also began to apply pressure to manmade images (Shmitt 2002, 79-104; Vauchez 1999, 81, 84-85). The church practices that Geary describes officially entailed symbolic, rather than physical, action against reliquaries or crucifixes. They were denied the honor properly due to them or were covered with thorns, but never struck, or, in the event that they were struck, those techniques were not part of the legitimate framework of the ritual, and were not recorded by the sources, since they were regarded as unbecoming of clerics.

It is important to note, however, that it was not only monks and canons who resorted to forceful pressure against holy objects, but laypeople as well. The range of measures that they regarded as permissible were also apparently much broader, even from the point of view of the clergy. For example, the eighth book of "The Miracles of St. Benedict" (8:6), complied by Raoul of Tourtier (Rodulfus Tortarius, died 1122), describes Adelard, the manager of a distant property 
of Fleury Abbey. Rather than protecting the local peasants, Adelard was oppressing them in a wide variety of ways. At one point, one of the women sought to bring him to justice, so she resorted to extreme measures. She went to the church, pulled the cloth from the altar and proceeded to lash the stone as if it was the saint himself (increpans quasi praesentem patrem Benedictum): "decrepit Benedict, sleeping laggard, what do think you're doing? Are you really sleeping? Why do you subject your servants to such injustice?” (De Certain 1858, 28284; Geary 1979, 38). ${ }^{3}$ This "forceful" prayer worked, and God chastised Adelard. One day, when he was escaping from his enemies on horseback, he accidentally stabbed himself in the throat with his own lance. As in the case of monks or canons humiliating their own holy items and appealing to their patrons, this story (and similar ones) describe laypeople in need of help turning to their "natural" heavenly protector (Saint Benedict, in this case, since they lived on his lands). Unlike practitioners of ritualized and largely symbolic humiliation of holy items, they applied direct physical force, demanding that the saint awaken from his sleep and come to their aid. In this context, it is highly illustrative that Raoul of Tourtier does not pass judgment on the actions of this despairing peasant woman who demanded relief rather than meekly awaiting it.

\section{The Catalyst for a Miracle}

If you go into Notre Dame Cathedral in Chartres through the western door and then deeper into the nave and look up at one of the stainedglass windows, you will see a scene at the very top of a man in a red tunic and green cap whipping a golden statue of a saint resting on a short column. If you go even farther, into one of the chapels of the deambulatory, this story will appear again, but now it is not a threedimensional image, but a flat one, an "icon" (fig. 2) (Harris 2008, 11942; fig. 1-2 [463-64]; fig. 3 [465]).

3. A similar story can be found in "The Miracles of St. Carilefus of Anisole" (Miracula sancti Carilefi, 1-2). The serfs living on the monastery's property were abused by the local baron. They entered the Church of their protector and proceeded to say tearful prayers to him; they then tore off the altar cloth and began to whip the altar itself, berating their patron for sleeping and forgetting to protect them (Cur hic obdormiscens nostri oblivisceris). The guard heard the noise and drove them from the church. The saint did help them, though; soon after, the evildoer who had been oppressing them fell from his horse and broke his neck (Acta sanctorum 1719, 651). 


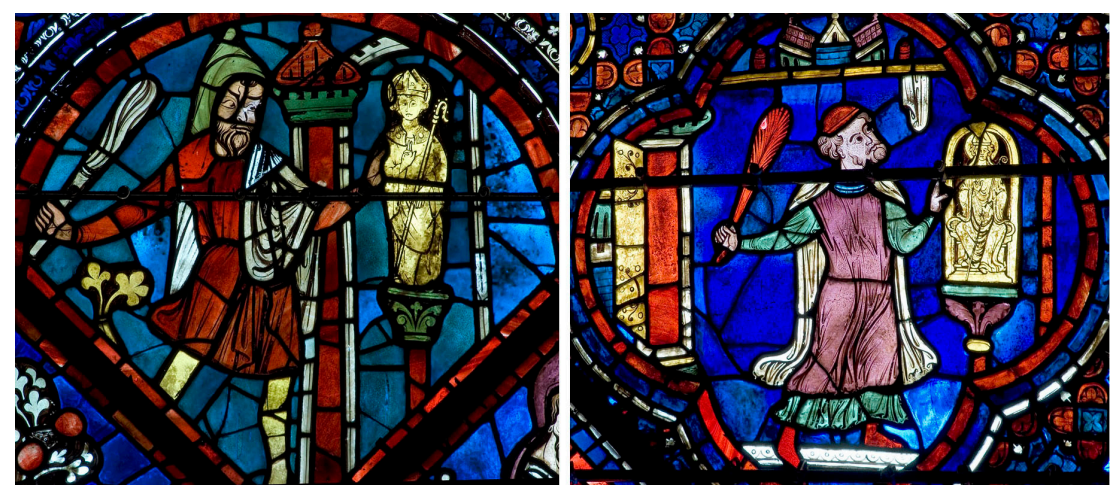

Fig. 2. A Jew beats an image of Saint Nicolas. Stained-glass image in the nave (left) and deabumlatory (right) of Chartres Cathedral, 1210-1235.

These scenes of beating the saint, created in 1210-1235, resemble the countless medieval images in which the apostles, monks, or bishops smash the gods of other religions ("idols"). In this case, however, the roles have been assigned in a fundamentally different way. The man with the lash is an adherent of a different faith, a Jew, and the statue or "icon" he is beating is an image of Nicholas of Myra, one of the most popular Christian saints. This beating is not a crime for which a wrathful Nicholas should, according to the rules of the hagiographical genre, have instantly chastised the evildoer, but rather the prologue to a miracle of an entirely different sort.

These two stained-glass images in Chartres illustrate a famous legend about the icon/statue of Saint Nicholas (Iconia sancti Nicolai). ${ }^{4}$ This legend appeared among the Orthodox Greeks who populated southern Italy in the tenth century, and then spread to the Catholic West, where it became widespread in the twelfth to thirteenth centuries (more specifically, it was included in "bestselling" hagiographies such as the Golden Legend by Jacobus da Varagine [circa 1260]). According to the ancient Latin version (from a life of Saint Nicholas written circa 890 by John, the deacon of Naples), the main character is not a Jew, but a pagan (a barbarian/Vandal). He found an icon (tabula) of Saint Nicholas, and learning about the power of this sanctifier from the Christians, left it to guard his treasures. While he

4. In addition to Chartres, a whipping of Saint Nicholas producing positive results appears in a stained-glass window of the Church of Saint-Julien-du-Verdon in Burgundy (Camille 1989). See also the miniature painting from the Flemish book of hours in the early sixteenth century, where a Jew in a pointed "Jewish cap" whips a gilded statue of Saint Nicholas on an altar: Oxford, Bodleian Library, Ms. Douce 112, Fol. 160. 
was gone, his home was ransacked. Enraged that the "icon" had let him down, he gave it a lashing and threated to throw it in the fire if the saint did not help him. As if he had suffered the lashing himself (nimia miseratione ductus super achonam suam ac si ipse flagellis caederetur), Saint Nicholas appeared to the thieves and reproached them for how badly he had been beaten on their account (et ideo pro vestro scelere ego innocens quam graviter flagellis caesus sum), and then threatened that if then did not return what they had stolen, they would be punished by death. That same night, the criminals secretly returned what they had stolen, and the pagan owner, finally convinced of the power of the Christian saint, soon received baptism (Brunet and Quentin 1910, 306-7; Choffari 2012, 212). In later versions of the story, such as the one in the Golden Legend, the icon was replaced with a statue (a more familiar cultic image in the West) and the main character was transformed from a barbarian/Vandal into a Jew (or occasionally a Saracen) (Graesse 1850, 27-28; Voraginskii 2017, 56-57; Camille 1989, 127-35; Vauchez 1999, 82-83; Sansterre 1989, 128-29). Pagan, Jew, or Muslim, this character was always an outsider.

There would have been nothing unusual about this legend (a miracle as an instrument leading followers of other religions to receive baptism and Christian sinners to seek redemption), if it were not for the moment when the character lashes the icon. Saint Nicholas's complaint is not against the one who has done him wrong, but rather against the thieves who "betrayed" him, leading to his being punished. In the oldest Latin version, the barbarian/Vandal, having applied the first type of pressure (lashing), blackmails the icon/saint with fire, and immediately St. Nicholas appears to those who caused his distress. In the Golden Legend version, the motive behind the act of blackmail is not directly expressed (the Jew's actions are referred to as ultio, "vengeance,") but the meaning and consequences of what he does remain the same.

The blackmail/punishment directed toward Saint Nicholas through a material image of him is not presented as sacrilege, but rather as a "pretext" for a miracle leading a follower of another religion to salvation. There are numerous medieval stories of Jews attempting to force Christ to undergo the Passion once again, supposedly torturing or crucifying crucifixes stolen from Christians or specially prepared wax figurines. They too often end with miracles (the image usually begins to bleed) and the conversion of (some) torturers. Unlike the lashing of Saint Nicholas, however, any aggression 
against images of Christ in these narratives was unambiguously interpreted as a crime committed out of hatred for the Savior and the Christian faith. ${ }^{5}$ Here, however, a follower of another religion lashes an image of the saint because it failed to meet his expectations, and what awaits him is not punishment, but a two-fold reward: Saint Nicholas returns his stolen treasure and he receives baptism, receiving a chance to save his soul.

The initial goal of the follower of another religion (either paganism or Judaism) as a character in the story is to protect his possessions. The goal of the story itself, as a single miracle constituting part of the life of Saint Nicholas or an image in a stained-glass window in a cathedral, is to glorify the power of a Christian image, to show that the saint acting through it is even prepared to descend to the level of those who do not (yet) believe in him, though he trusts him to guard his property, and to demonstrate the triumph of Christianity over any other religion by leading him to receive baptism. The finale of the story a posteriori justifies the radical measures that the main character takes against the icon/statue.

\section{Image as Hostage}

It is extremely important that more and more instances of this story began to appear in thirteenth-century Church teachings, in which coercion humbly inflicted on religious images in the hope that they would produce a miracle is presented as a legitimate method of acting on (images of ) saints, not only for followers of other religions, but also for Christians themselves.

In 1219-1223, the Cistercian monk Caesarius compiled a "Dialogue on Miracles" for the novices he was responsible for instruct-

5. Early medieval stories of miracles (primarily bleeding) and manifestations associated with religious images in response to aggression by followers of other religions (most often Jews) or iconoclasts, were rare in the West, compared to Byzantium. They began to become widespread in the eleventh to thirteenth centuries, when a tremendous expansion of the cult of images occurred in the Catholic world north of the Alps, and went on to draw closer to saints' remains and other relics in terms of their sacred status. At the same time, tension in Jewish-Christian relations led to the formation of a whole range of accusations associated with torturing the body of Christ: through images of it, through the bodies of Christian infants (the "blood libel") and through the Host (see Sansterre 1999). It is important to note that the miracles performed by religious images in response to aggression by Jews, heretics, or Catholic blasphemers were not solely promulgated for the sake of polemics against Judaism or heresy. Just as they did in the East, they served as a catalyst for reverence toward particular religious images and were regarded as foundational to the cult of images as a whole. 
ing at Heisterbach Monastery, near Cologne. This book was an immense collection of exempla, illustrating the fundamental provisions of Church doctrine. In addition to dozens of times that Christ, the Virgin Mother, and the saints appeared, provided healing, or inflicted punishments through images, he also narrated an instance of successful blackmail (7:45).

In the chapel of Veldenz castle, there was a wooden statue of the Virgin Mary with the Infant Christ, crudely made, but endowed with great power (virtus). A lady named Jutta who lived in the castle passionately revered it. Once, when her three-year-old daughter who lived with her wet nurse in a neighboring village went out to play, a wolf carried her off into the forest. When she found out what had happened, Jutta ran to the chapel, took the infant Christ away from the Madonna, and tearfully shouted: "My lady, you will not get your child back until you return mine to me!" The girl was soon found alive, and Jutta gratefully returned the Virgin Mary's infant (Strange 1851, 2:62-64; Baschet and Dittmar 2015, 167-76; Sansterre 2010, 171-73). According to Caesarius, he heard this story from Herman, the abbot of the Marienstatt Monastery, who heard it directly from Jutta herself.

The despairing mother removes the figure of Jesus from the statue of the Virgin Mother (by breaking it off, perhaps?), not because she wishes to punish the image or deny its power, but rather to activate that power and force the Madonna to answer her prayer. It is highly illustrative that Caesarius presents this story immediately after an account of another lady from the same castle who mocked the statue as ugly and was punished by the Virgin Mother for doing so. The woman's son took all her property and threw her out of the house, forcing her to resort to begging to avoid dying of starvation. Pious blackmail is permissible, impious mockery is not.

Several versions of this story of the Virgin Mary being blackmailed through the figure of her infant can be found in compilations of thirteenth- to fifteenth-century exempla. In these texts, Jesus is seized by a pious but despairing mother whose son has been taken captive by enemies or even hanged for some kind of crime. Thanks to the mercy of the Virgin Mother, the prisoner returns at once, or the executed man is resurrected (Tubach 1969; Vaucher 1999). ${ }^{6}$

6. This story appears in another thirteenth-century compilation, produced by Caesarius von Heisterbach (Dialogus miraculorum), the Epilogum in gesta sanctorum by the Dominican Bartholomew of Trent, the Golden Legend by Jacobus da Varagine, the Canticles of Saint Mary by Catholic king Alfonso X, etc. In the fourteenth century, it can 
This story was periodically transposed into the realm of iconography. For example, it can be seen in the magnificent manuscript "The Miracles of Our Lady" by Jean Miélot, which was created in 1456 for Philip the Good, duke of Burgundy. The illuminator Jean Le Tavernier depicted a woman reverently taking the infant Christ from the statue of the Virgin Mary on the altar without a hint of discretion, in full view of the other worshippers (fig. 3). ${ }^{7}$ It is noteworthy that when the exemplum of the despairing mother first appeared in the Russian literary tradition in the seventeenth century, the statue of the Virgin Mary, which was uncommon in Orthodox cultic practices, was replaced with an icon in both texts and miniature paintings. The "abduction" of an infant painted in his mother's arms ought to be regarded as a miracle in and of itself, however; unlike a figure carved from wood or stone, it could not simply be removed. Nonetheless, the Russian adaptation of this story does not offer any commentary on this point, or attempt to explain it. For example, in the miniature paintings in an Old Believer compilation from the eighteenth century, one can see the despairing mother whose son has been thrown into the dungeon on false charges, holding the infant Christ (who was just sitting in the Virgin Mother's lap) (fig. 4), and then carrying it home with her to hide it in a chest. ${ }^{8}$

It was not only the Virgin Mary who became the object of this form of blackmail. For example, the Chronica majora by British chronicler Matthew Paris describes an abbess deciding to coerce the apostle Paul to come to her aid, but does not pass judgment on her. In 1224, the Norman knight Falkes de Breauté, seeking to reinforce his castle in Bedford, destroyed a church dedicated to that saint. When she learned

be found in the De introductione loquendi by the Dominican Filippa da Ferrara, the Alphabetum narrationum, by Arnold of Liège, also a Dominican, in a compilation known as Ci nous dit, and in the fifteenth century in "The Miracles of the Virgin Mary" by Jean Miélot. The story can be found in the Thesaurus Exemplorum Medii Aevi (http://gahom. huma-num.fr/thema/) database (entry 1024 in the index of the Tubach fond).

7. Paris, Bibliothèque nationale de France, Ms. Français 9198, fol. 137v. Two versions of this same story can be found in the miniature paintings in the Parisian manuscript, "The Miracles of the Virgin Mary" by Gautier de Coincy: The Hague, Koninklijke bibliotheek, Ms. 71 A 24, fol. 123v, 174.

8. The description of the mechanism of the abduction and later return of the infant to the icon presented in the text is extremely brief; "lay your hand on the image of the Virgin Mother" (Saint Petersburg, Library of the National Academy of Sciences, 32.3.15, ll. 113, 116). This miracle can also be found in the illuminated manuscript "The Brightest Star," created in 1686 in the Novodevichy Convent: BAN P. I. A. no. 58, 1. $1510 b .-152$. 


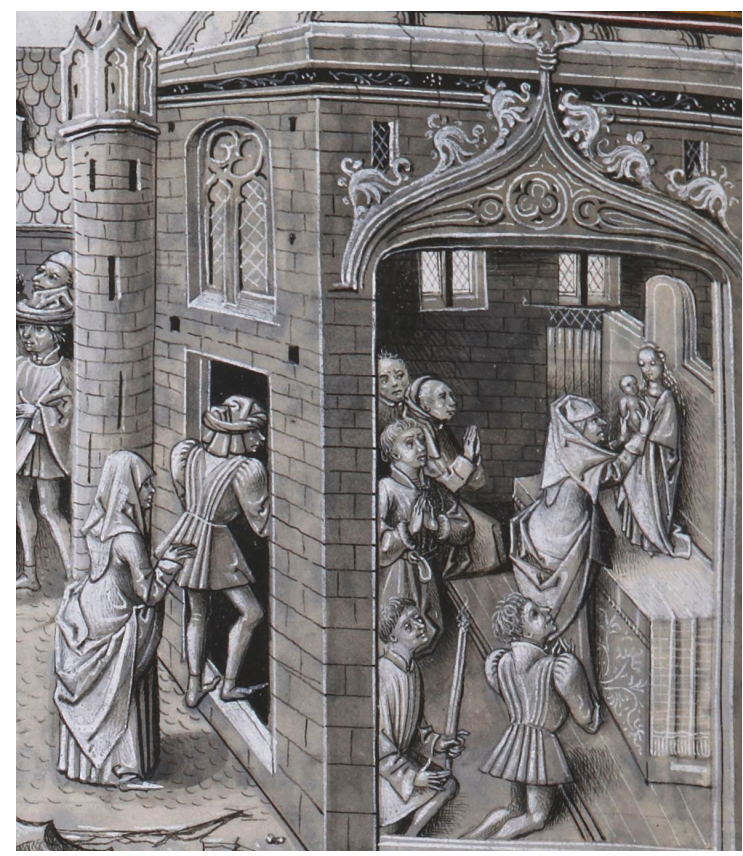

Fig. 3. Woman removes the Virgin Mary's son from her statue. Illustration from "The Miracles of Our Lady" by Jean Miélot, 1456 (Paris. Bibliothèque nationale de France. Ms. Français 9198. Fol. 137v).

that his crime had gone unpunished, the abbess of the neighboring monastery ordered that the sword be removed from their statue of Saint Paul until revenge had been taken for Falkes's deed. That castle in Bedford ultimately fell (Luard 1976, 3:87; Sansterre 2013, 72). The abbess's actions follow the same logic as the ritualized humiliation of crucifixes and images of the saints that would be discussed at the Second Council of Lyon fifty years later. The only difference, judging by Matthew Paris's description, is that her "forceful" appeal to the apostle Paul was not accompanied by a suspension of services, and that his statue was not humiliated by removing it from the altar and covering it with thorns, but rather directly blackmailed by removing its main iconographic attribute, the sword.

In such stories, blackmail is presented as an effective and fully legitimate (i.e., legitimized by the fact that it proves effective and leads to a miracle) method of interacting with higher powers. If the narrator judges that the petitioner's aim is noble, and his attitude to the image is respectful, then almost anything is permissible. In another context, however, (for example, if the Jew who whipped Saint Nicholas was not 


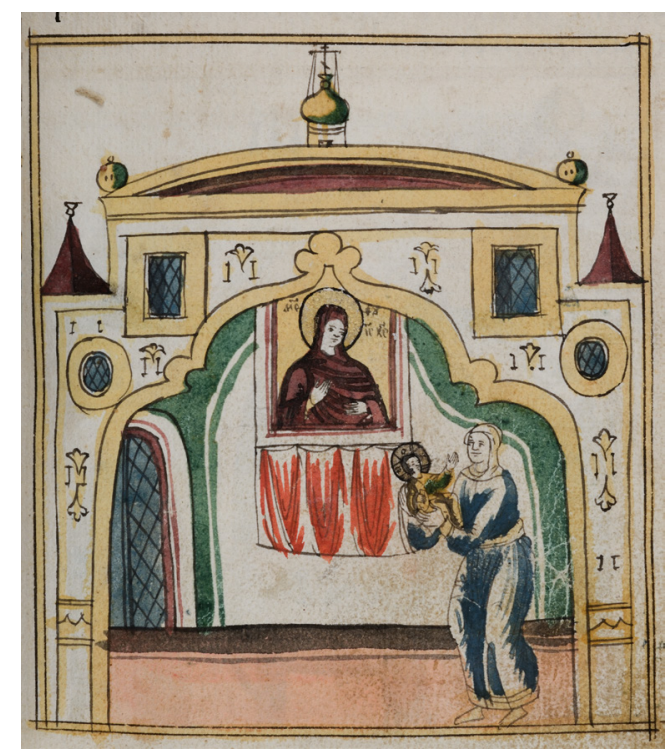

Fig. 4. The Orthodox version of the story: an inconsolable mother removes the infant from an icon of the Theotokos (Saint Petersburg, Library of the Academy of Sciences, 32.3.15., l. 113.

baptized thereafter, and the infant Christ was taken away with blasphemous curses by a heretic) the same act would have been interpreted as sacrilege. There are countless such examples.

\section{Quasi-violence}

Successful blackmail against higher powers creates the impression that the saints are dependent on man, that by creating images from wood or stone people took their heavenly patrons hostage and could manipulate them as they pleased. Seemingly seeking to divert the reader from potentially dangerous interpretations, Caesarius von Heisterbach wrote that the Virgin Mary ordered the wolf to return the child "as if" (quasi) she was afraid that Jutta would not give Jesus back. In other words, blackmail only proved effective because the Madonna showed mercy to a pious woman, not because the Queen of Heaven can actually be coerced by abducting the infant from one of the countless statues of her. ${ }^{9}$ The story of the Jew and Saint Nicolas, as presented in the

9. When he recounted the same story in the fifteenth century in his Promptuarium de miraculis Beatae Virginis (no. 15), Johann Herolt emphasized that the weeping, 
Golden Legend, is also analogous; the saint "appeared to the thieves just as if he himself [tamquam in se] had suffered blows" and rebuked them: "look, my body is covered in wounds . . . which the Jew inflicted upon me because you stole his treasure" (Graesse 1850, 27-28; Voroginskii 2017, 57; Sansterre 2009, 54n32). Although Saint Nicholas both voices complaints about the wounds that he bore due to his punishment and paints them in the most physiological light possible, the text uses the qualification tamquam in se to emphasize that the saint, who abides in the heavens, cannot experience physical pain, and partially removes the danger that identifying the image with what might be called the "prototype" or "preimage" underlying it would present from the perspective of dogma, despite the fact that this identification is the basis on which the idea of punishment or blackmail against a saint is built. ${ }^{10}$

Church texts often (but far from always) explain that "forceful" prayer only proves effective due to mercy shown by higher powers. This, however, does not remotely mean that actual blackmailers also imagined a "mechanism" of coercion in a strictly orthodox sense. The cultural (if not psychological) roots of the practice of punishment/ blackmail are deeper than the Christian cult of saints and the Christian theory of images. They rest on an ancient intuition that what is depicted in an image is present in that image (different cultures explain this in different ways), and that actions performed on the image are somehow transferred to what it depicts. Theologians have explained that images of saints do not have any inherent power (God simply creates miracles through them) and that Christians who appeal to two- or three-dimensional images are using those material ob-

despairing mother took the infant Christ, and the Virgin Mary took pity on her bitterness, as if she was afraid of losing her son if she did not return the woman's daughter to her (quasi timeret filio suo carere): (Herolt 1606, 8-9). In describing the miracles that occurred in response to pious blackmail, writers often emphasize that before taking action, the petitioner would pray and weep. Regardless of how accurately this detail reflected real practices, it undoubtedly served as a rhetorical alibi that clearly distinguished between pious and willful sacrilege.

10. The Latin word quasi and analogous words in other languages occur regularly in church texts describing religious images that miraculously "come to life." Without ever casting doubt on these miracles, they remind the reader that their external forms are signs of reality, rather than reality itself (Sansterre 2015, 160, 168). Similar formulations are also often used in Catholic descriptions of "torture" or "executions" Protestant iconoclasts inflicted on crucifixes or figures of saints, as if they were tormenting not images made of stone or wood, but those depicted by those images (Christin 1991, 133 137). The Catholics were apparently also "returning" the iconoclasts' rebuke for expecting miracles from pieces of wood or stone. 
jects to direct their prayers to their invisible prototypes. In the consciousness of many believers, however, the most important thing by far was probably a simple feeling: the statue or icon really was the saint, experienced through sensation. This is not grounds to conclude that they had fully blended the image and its prototype; it is simply that for them, the power of their heavenly patron was embodied in a specific image with which they were familiar (see Baschet 2008, 3944). Since an image can receive honor and prayers, it follows that it can also accept dishonor and punishment.

It is, however, worth noting that in those cases of blackmail against saints that church authors present as a legitimate practice, the harm inflicted on the images is invariably temporary and reversible. The barbarian/Jew/Saracen subjects the icon or statue of Saint Nicholas to flagellation or threatens to burn it if it does not come to his aid, but he never actually burns it, of course. Pious blackmailers removing the infant from a statue of the Virgin Mary or the sword from a statue of the apostle Paul return them as soon as they receive what they want. After lengthy prayers, despairing mothers respectfully remove the wood or stone infant from the Virgin Mary, take it home, carefully wrap it in cloth and lock it in a chest, pleased that they now have collateral or a hostage (obses in Latin or ostage/gaige in French) that will return their own son to them. ${ }^{11}$ The most irreverent method (and the one closest in form to what would typically be interpreted as sacrilege) was used by the main character of Iconia sancti Nicolai, who is a follower another religion (a pagan, Jew, or Muslim). None of the Christian petitioners/blackmailers in similar exempla manhandled the statue. Furthermore, it is important to note that these stories invariably conclude by establishing or restoring the relationship between the viewer and the sacred person whose help they demanded in such an unusual fashion, due to an "overabundance" of faith and hope, not a deficit. ${ }^{2}$

11. For example, see the Golden Legend (Graesse 1850, 591-92) or the eighth book of the Dialogus miraculorum by Caesarius von Heisterbach (Meister 1901, 205-6). In the Franciscan compilation of exempla from the 1270 s, published by A. G. Little, the despairing mother did not even manage to take the divine infant away from the Virgin Mary. As soon as she threatened to do so and extended her hand toward the statue of the Virgin Mother, her son appeared instantly and shamed her; "What are you doing, mother? Look, the Virgin Mother has returned me to you!” (Little 1908, 30).

12. Obviously, many other stories, which do not conclude with the believer "reconciling" with the saint, were simply classified by Church authors as sacrilege, or remain completely unknown, since they did not have educational value, and were therefore never recorded. 
This is likely why the story of the despairing mother continued to wind its way through compilations of exempla, even in the post-Tridentine period, when the Catholic Church charted a course toward purging the cult of images of everything that suggested folk superstition (see below), drew dangerously close to magical practices, smacked of irreverence toward the saints, or blurred the boundary between image and prototype. In 1603, the Jesuit Jean Major published a hefty tome in Douai entitled Magnum speculum exemplorum. In the section dedicated to the Virgin Mary (B. Maria Virgo, no. 32), he includes a reference to the Golden Legend and offers the "example" of the act of blackmail against her statue. It is, however, suggestive that the introduction of the story characterizes the mother's actions as an example of "pious simplicity" (pia simplitas) (Major 1633, 541). By that time, punishment or blackmail directed against saints was already most often considered impious, a superstition and/or sacrilege (blasphemy). Nonetheless, the narratives of such methods, insofar as they were sanctified by the authority of tradition and legitimized by the appearance of a miracle in response, were not fully discredited.

\section{Inviolable Sacred Objects}

The turning point in the official history of punishment/blackmail directed against saints was the Second Council of Lyon, convened by Pope Gregory X in 1274. The Church hierarchs assembled there demanded that the canons not suspend public services (cessatio a divinis) without providing canonical justification for their right to do so, and informing the person against whom this measure was directed of their plans in writing. At the same time, the humiliation of crucifixes was flatly prohibited as dishonorable abuse (detestabilem abusum horrendae indevotionis) (Mansi 1780, 24:92). ${ }^{13}$ Patrick Geary primarily connects this sea change with the administrative centralization of the Catholic Church and the hierarchy's attempt to deny the clergy such a powerful (and, more to the point, unregulated) in-

13. In the late thirteenth century, Guillaume Durant, the bishop of Mende, wrote in his liturgical summa Rationale divinorum officiorum (1:13) that the Thirteenth Council of Toledo once permitted clerics to remove the cloth coverings from altars and religious images and cover them with dark (funerary) cloth or thorns, in the event that they were doing it in defense of the rights of the Church. That was in the ancient past, however In his own time, the Second Council of Lyon had already passed judgment against the practice (Durand 1614, 1:12; Thibodeau 2007, 31). 
strument as blackmailing sacred objects (Geary 1979; Shmitt 2002, 110-11).

It is not advisable, however, to lose sight of the ideological dimension of this problem. As early as the twelfth century, removing the cloths from altars and other methods of humiliating the higher powers were mentioned by Gratian in his monumental code of canon law, Concordia discordantium canonum, or Decretum (2.27.5.12-13). In his text, they are presented as an instrument of pernicious witchcraft (maleficia nequissima) that clerics occasionally indulge in. Gratian casts judgment on priests who inflict harm on their enemies by uncovering altars, putting out candles, and then holding funeral masses for them (Friedberg 1959, 1031-32). ${ }^{14}$ For many thirteenth-century theologians, the boundary between reverent coercion against sacred objects and sacrilege/blasphemy had begun to seem too ambiguous. The decision of the Second Council of Lyon formally only applied to canons, and the only method of humiliation that figured in it consisted of dropping sacred objects onto the floor and covering them with thorns. In 1289, Raimond de Calmont d'Olt, the bishop of Rodez, released synodal statutes in which the list of forbidden practices was expanded. In addition to cessatio a divinis, he mentioned that certain clerics would respond to heat waves or thunderstorms by abusing sacred images, and that crosses or statues were not simply humiliated, but also subjected to flagellation, broken, pierced, or submerged in water (Martène 1717, 4:633, statute 20).

Numerous accounts that have survived from the late Middle Ages and early modern period suggest that people in various parts of Europe would respond to droughts or excessively strong rains by throwing or dipping relics or images of saints into rivers, streams, fountains, or wells. This method, based on the principles of sympathetic magic, was meant to either summon or stop rainfall (water attracts or repels other water). The origins of such practices can certainly be found in numerous pre-Christian cults, but the question of how they emerged

14. This fragment of the Decretum consists of quotations taken from two ancient texts dedicated to completely different questions. The first is a decree of the Seventeenth Council of Toledo (694), regulating cessations of services and humiliation of relics during the course of personal conflicts and shared disasters, and the second is a decision by the Thirteenth Council of Toldedo, which condemns saying prayers of remembrance for the living (Mansi 1766, 12:99, see cap. 5). Gratian's thirteenth-century text, condemning the removal of cloths from altars as an element of magical masses, copies or paraphrases other lawyers and theologians, such as Raymond of Penyafort (Summa juris canonici) and Vincent of Beauvais (Speculum doctrinale). See Barnum 2004, 2:67; Montesano 2000, 42:2. 
and were "Christianized" falls outside the scope of this article (Santyves 1933, 144-92). The salient point is that, according to the Rodez statutes, it was not only laypeople who submerged relics in water, but also clerics, and that it was not merely "forceful" personal prayer, but a collective ritual. ${ }^{15}$

In the late fifteenth century, this question was investigated in great detail in a tract entitled "On Superstitions," which was compiled by Martinus de Arles y Andosilla (Martin of Arles), a canon from Pamplona. ${ }^{16}$ It belongs to a long sequence of texts dedicated to debunking superstitions, which began to appear on a large scale throughout Europe in the late fourteenth and early fifteenth century. Although criticism of superstitio (this category covered both remnants of paganism and illegitimate distortions of legitimate church practices) was an important part of the discourse of clerics in the early centuries of Christianity, it acquired special urgency in the late Middle Ages, as Michael Bailey demonstrates. In many ways, this is connected with the fact that Church preaching, with its mission of religious acculturation, was penetrating into the vast world of the peasantry more and more actively. Long before the Counter-Reformation, the authors of tracts on superstation (university theologians or practicing pastors) set the goal of uprooting or correcting the numerous forms of folk religion that did not fit into the framework of official piety and were often based on appropriating elements of Church rituals for magical purposes (Bailey 2009, 633-64, 657; see also Ankarloo, Clark, and Monter 2002, 4:105-21). It is not surprising that by the mid-fifteenth century, the radical demonization of magical practices led to the formation of a cumulative concept of sorcery, which became the ideological foundation of witch hunting. ${ }^{17}$

15. There is ample evidence to suggest that this method of summoning or halting rain, as well as punishing saints for various climatic disasters was alive and well as late as the nineteenth century. For example, on September 6, 1815, after a long drought, the clergy of Périgueux went to the spring of Saint Sabina to throw in a cross, and circa 1830, the residents of Villeneuve-Saint-Georges, near Paris, threw a statue of their patron saint into the Seine or one of the smaller nearby rivers, because their vineyards suffered frost damage (Santyves 1933, 162-63, 179).

16. This text was first published in Lyon in 1510, and then republished several times: in Paris in 1517, in Rome in 1559, in Frankfurt in 1581, and in Vienna in 1584. See Gaztambide 1971, 249-66; Bailey 2009, 636n21, 637, 644, 649-50.

17. See Schmitt, 2002, 131-49. Martín de Andosilla (Martin of Arles) also dedicated several pages to witches flying to their nighttime gatherings, but he believed, according to the old fashion, that witches were not transported there in reality, but only mentaliter et fantastice (Gaztambide 1971, 276-77). 
If in the Rodez statutes, which repeat the formulation used by the Second Council of Lyon, whipping or submerging sacred images was characterized as "horrible abuse" (abusum detestabilem), Martin of Arles explains such practices as both superstition and sacrilege. Furthermore, his tract dedicated to criticism of superstition (from divination and love spells to belief in auspicious and inauspicious days), begins by discussing (and passing judgment on) blackmail against a statue of Saint Peter. According to this canon from Pamplona, the reason he put pen to paper at all was to dispel the doubts of his colleague, the archdeacon of the village of Usun, in Navarre, who described an old custom to him. When a drought occurred, the clergy and the citizens would organize a procession to the Church of Saint Peter. Once the mass had been performed, they would say prayers as they removed the image of their heavenly patron from the altar and then carried it to the river. One of those present would appeal to him: "Saint Peter, help us in this time of need, implore God to give us rain." They would repeat this process for a second and then a third time. When they received no answer, the people would begin to shout for the image of Saint Peter to be submerged in the water, if he would not intercede on their behalf and alleviate their misfortune. Then a prominent local (primatibus) would answer that that wouldn't do, but Peter was the good shepherd, and he would implore God to give them what they wanted. The residents insisted that there had never been a time when they were betrayed and their expectations were not met; rain would always come within a day (Gaztambide 1971, 271-72).

It is highly illustrative that the algorithm for action taken toward an image and its prototype described by Martin of Arles based on the account from the archdeacon of Usun is so close to the pragmatics typical for iconoclastic rituals. In numerous descriptions of solitary and collective attacks on Catholic "idols" that occurred in different parts of Europe during the Reformation, the same scenario regularly recurs. Before "executing" an image by breaking it into pieces, shooting it with harquebuses, or throwing it in a fire, an iconoclast would address it as if it were a living person, demanding that it speak, offer resistance, save itself, or begin to bleed. When this address went unanswered and no miracle occurred, he would "gouge out" its eyes, break it apart, or throw it in a fire, as if enraged by the graven image's silence. By (deceptively) demanding that dead "idols" show signs of life, the iconoclast parodies the actions of Catholic "idolaters" and strives to demonstrate to onlookers (and perhaps to himself?) 
that graven images are powerless, to show (and confirm?) that they are incapable of defending themselves, and are therefore empty and dead, that they are merely the product of human hands, objects that do not contain any kind of subject (Scribner 1987, 110-14; Christin 1991, 131-38; Maizuls forthcoming). Bruce Lincoln once called this process "profanophany" (in contrast to "theophany"), that is, the appearance of emptiness, the non-divinity of another's holy image (Lincoln 1989, 103-27).

A provocative/playful address to an "idol" is a polysemous gesture. Its meaning fluctuates between testing the power of an image and ritualistically demonstrating its powerlessness; it is directed toward viewers (former or current "idolaters"), but it can simultaneously serve an autosuggestive function. Mustering sufficient resolve to physically attack a religious image (which you revered as recently as yesterday, which others still revere, and which represent religious and political order) requires using mockery to overcome one's fear of them and/ or the ensuing violence that prevents one from going back. The similar ritual performed in Usun, with its series of addresses to an image (which ultimately remains silent and does not immediately perform a miracle) is intended not to demonstrate the powerlessness of the statue, but rather to activate its power with a threat. Rituals of "profanophany" such as those practiced by Protestant iconoclasts in the sixteenth century reject the Catholic cult of images by taking its most radical forms to their logical limit.

Martin of Arles condemns blackmail against Saint Peter as simultaneously: (1) superstition; (2) sacrilege; (3) an attempt to tempt God by checking or testing his power; and (4) a sinful enticement, a "scandal." It is a superstition because rather than praying to the Lord for rain, the residents of Usun demanded that their request be fulfilled not by the Creator, but a creation (the statue). By immersing it in water, even when accompanied by Church hymns and chanting, they had gone beyond what is permissible in the realm or reverence toward (images of) saints and actually inflicted an outrage on them (iniuriam sanctorum). This same gesture is sacrilege. After all, according to the definition presented by Thomas Aquinas in the Summa Theologica (2.2.99.1), a physical attack against images of the saints, as well as other holy items, transfers this dishonor from the image to its prototype. Why then does blackmail prove effective, and cause heaven to grant the much-needed rain? Because that rain has been arranged (with God's sanction) by the devil, in order to seduce the people. After all, demons are capable of acting upon bodies and natural 
elements, and they often perform pseudo-miracles (Gaztambide 1971, 274-75, 304-14). ${ }^{18}$

If punishment/blackmail directed against saints is sacrilege, then violence engendered by (superstitious) faith in the power of the image belongs in the same category as attacks by followers of other religions, heretic iconoclasts, or Catholic freethinkers, who struck out at images of sacred persons, denying their power or at least attempting to challenge it. Theoretically, sacrilege engendered by an "overabundance" of faith was subject to the same punishment as that engendered by a "deficit." In practice, however, a demonstrative challenge to the entire cult of images (and, through it, a challenge to the power of the clergy, and the practices of salvation on which that power was based) probably provoked a sterner punishment than superstitious "excesses." In an analogous fashion, after the emergence of Protestant iconoclasm, those committed to the struggle against Catholic "idols" who destroyed religious images were punished as heretics, while drunken gamblers who threatened figures of the saints "in the old way" without any accomplices or ideological motives for their actions could count on gentler treatment (see Christin 1999, 18-22). In the Late Middle Ages and Early Modern periods, Catholic Europe did not have a single scale of punishment for physical aggression against religious images. Depending on local laws, the political context, and the social status and reputation of the criminal himself, as well as potential mitigating circumstances (like intoxication), punishments might include Church penances, a monetary fine, wearing a mitre of shame, a public flogging, or even execution by hanging or burning at the stake (see Konnell and Konstebl [Connell and Constable] 2010, 65-69, 77-93).

As has already been shown, the essence of such a crime could be classified as either sacrilege (sacrilegium) or blasphemy (blasphemi$\mathrm{um}$ ), and the boundary between these concepts was unstable (Konnell and Konstebl [Connell and Constable] 2010, 77-78n3, 90; Christin 1994, 43-64). For example, the legislative code Las siete partidas $(7,28,4-5)$, created in 1256-1263 during the reign of the king of Castile, Alfonso X the Wise, which was still in effect in Spanish colonies in the New World as late as the Modern Era, characterized physical

18. The idea that any magical procedures (i.e., procedures that are illegitimate, even if they involve the use of Church texts and objects) cannot be effective in and of themselves, but they do "get the job done," that is only thanks to the intervention of demons and an implicit or explicit pact with them, can be found in many demonology tracts from the Late Medieval and Early Modern periods (Ankarloo et al. 2002, 117). 
attacks against holy images, from spitting at them, throwing rocks at them or striking them with a knife, as blasphemy. Furthermore, blasphemy in deed was to be punished more directly than verbal insults against sacred persons and objects. Verbal blasphemy by a person who had some kind of property would lead to the confiscation of a fourth of it for a first offense and exile from the city for a third, or, in the case of a person with nothing to take, fifty lashes for a first offense and the severance of his tongue for a third, while the prescribed punishment for blasphemy in deed was exile for a first offense in the case of person with property or the amputation of a hand in the case of a person with nothing to take (Lopez 1843, 4:670; Burns 2001, 5:1448-50). ${ }^{19}$ In the sixteenth century, the French jurist Nicolas de Bohier (Boerius) (1469-1539), in his treatise Decisiones aureae, refers to those who insult God de facto, by spitting or throwing rocks at images of Christ, the Virgin Mary, or the saints, guilty of blasphemy, rather than sacrilege (Bohier 1576, 615-18 [2:245 - On Sacrilege], 749-55 [2:301 On Blasphemy]). It is no accident that the chapter of Sebastian Brant's satire The Ship of Fools (Das Narrenschiff, first published in Basel in 1494), which is dedicated to blasphemers, opens with an engraving by Albrecht Dürer, depicting a jester attacking a crucifix with a trident (fig. 5).

It is important to note that the works of both Martin of Arles and the majority of other sixteenth- and seventeenth-century authors, theologians, and demonologists do not simply condemn blackmail/punishment directed against the saints as superstition and/or blasphemy (sacrilege); they place it in the same category as outright demonic magical practices. ${ }^{20}$ For example, Jean Bodin's famous tract “Of the Demon-

19. For more on blasphemers and how they were persecuted in colonial Mexico, see VillaFlores 2006. The system of different punishments based on the socioeconomic class of the offender was also maintained by the Synods of Florence in 1516-1517. If someone was moved by demonic malevolence to physically threaten an image of Christ or the Virgin Mary and he was a noble, he would have to pay a fine, whereas a common person would be put in chains and forced to wear a "mitre" of shame for three years. In the same situation, a cleric would be forbidden from performing services and suffer a loss of benefices (Konnell and Konstebel [Connell and Constable] 2010, 90).

20. Fifteenth- through seventeenth-century sources, from demonology tracts or texts on superstitions to court records and reports by missionaries, provide many examples of images of saints being appropriated for various magical purposes. For example, the authors of The Hammer of Witches (1486) describe how crucifixes would be broken into pieces in order to heal or protect various parts of the body: "Thus, if one wishes to be protected against wounds or blows to the head, he removes the head from an image of 


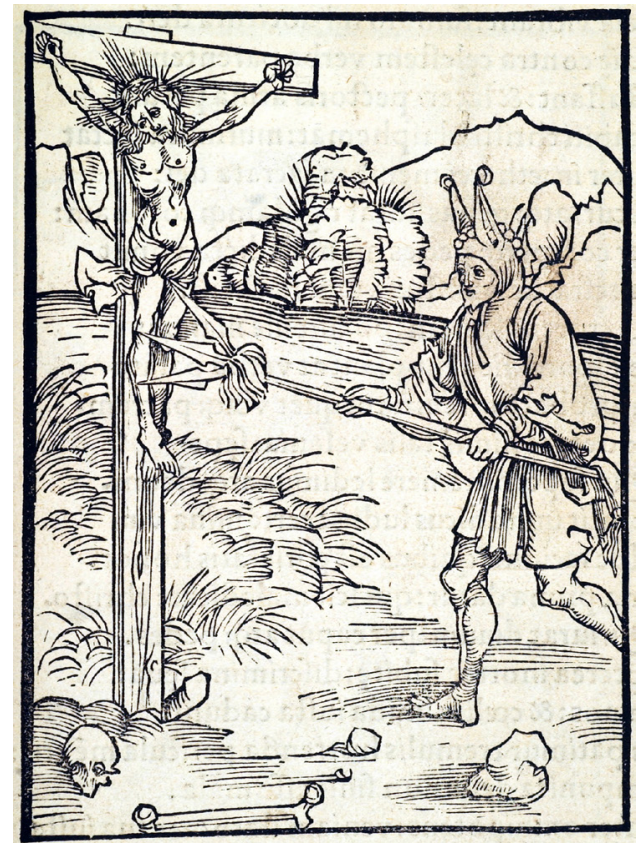

Fig. 5. A symbol of blasphemy: A jester attacks a crucifix. Illustration by Albrecht Dürer to a poem by Sebastian Brant, The Ship of Fools

(Basel, 1494).

mania of the Sorcerers" (1580) offers several examples of such abuses. The first was drawn from Giovanni Pontano's History of the Neapolitan War (1499) (Pontano 1509, book 5). During the conflict (14591465) between Neapolitan king Ferdinand I and rebel barons seeking to place John II of Anjou on the throne, royal troops besieged the village of Sessa, which was guarded by the French. Since terrible heat had set in, the besieged people were suffering from a lack of water. The priests (Bodin distorts Pontano's text and calls them "sorcerer-priests") took a crucifix to the shore under the cover of darkness and blasphemously threw it in the water. Furthermore, they fed the consecrated Host to a donkey and buried it alive at the threshold of the Church. ${ }^{21}$ Just then,

Christ. One who wishes to protect his neck from wounds takes that same part of the body from the crucifix. One who wishes to have his arm protected rips away the image of the arm from the crucifix, and so on. [. . .] As such, not one of the dozens of images of Christ standing at crossroads is whole" (Shprenger and Institoris 2001, 292, part 2, chapter 16).

21. In France, images of donkeys with the Host in their mouths (or devouring it) often appeared in the modillions of Romanesque churches. Kenaan-Kedar links this story with the Feast of the Ass (festa asinaria), in which the low-ranking clergy held a "mock 
a rainstorm began, such a deluge that the Spaniards were forced to lift the siege. According to Bodin, similar practices also existed in France. In 1557, he personally saw children in Toulouse attempting to summon rain by dragging crucifixes and statues to the river at midday; some then dropped holy items down a well. He believed that these simple people had learned this magical practice from sorcerers who were deliberately spreading their pernicious science (Bodin 1586, 193-94).

During the Counter-Reformation, the Catholic Church, faced with Protestant iconophobia and iconoclasm, set about "purging" its cult of images of narratives and practices that were dubious in terms of dogma or morality. The primary ideological guidelines were formulated in 1563 at the twenty-fifth session of the Council of Trent (See Canones et decreta 1856, 173-76). This brief outline still had to be developed into a coherent doctrine that would have distinguished genuine (and salvific) images from harmful, heretical ones, and legitimate practices from illegitimate ones. Louvain-based theologian Joannes van der Meulen (Molanus) and Gabriele Paleotti, the archbishop of Bologna, took on this task.

In his treatise De picturis et imaginibus sacris (1570), Molanus assigns punishment/blackmail directed against saints to the category of superstition, along with "drowning" religious images (of Saints Peter, Paul, and Urban) or relics (of Saint Felicitas) in order to summon or stop rain, the humiliation of crucifixes and statues during suspensions of services, and the usurpation of church images by sorcerers and witches (Molanus 1570, 57-59. Also see Freedberg 1982, 13353). In his unfinished text Discorso intorno alle imagini sacre et profane (1582), Gabriele Paleotti also condemned punishment/blackmail directed against saints as superstition (2:8) and incorporates it into a detailed taxonomy of impermissible images and associated practices. In his system, superstitions are a half-step between contentious images that merely have the potential to lead the viewer to incorrect beliefs, and openly heretical images that propagate false doctrines. ${ }^{22}$

mass" in honor of the flight of the Holy Family to Egypt and selected a Bishop of Fools for the duration of the festival (Kenaan-Kedar 1986, 314, 317-18, 330, fig. 1). According to another, more credible version of the story, the donkey (or, occasionally some kind of monster) with the Host symbolizes those who take communion without believing that it is the body of Christ, and thereby commit blasphemy (Weir 1999, 92, fig. 37a).

22. Paleotti distinguishes (2:3-9) between several types of dubious images: (1) challenging (temerariis) - when something merely possible is passed off as provably known, although the Church has not given it the stamp of approval (for example, in depictions of the Last Judgment, more priests than monks appear among the righteous); (2) scandalous (scandalosae) - when heretics who are incapable of refuting Church dogma attack the morals of its clergy and emphasize only the darkest and lowest 
Early Modern Catholic intellectuals saw punishment/blackmail directed against saints as one of the excesses of popular religion, as one of the points where the superstitions of simple Christians (who, in their view, were often Christians in name only) blended with the practices of pagans (who had yet to convert to Christianity). ${ }^{23}$ In the 1580 s, the Jesuit missionary Alessandro Valignano relied on information brought from China by Matteo Ricci, a fellow member of his order, to write that the mandarins did not show very much respect for their idols; the common people, however, prayed to them in temples and in their own homes, but nonetheless insulted them (y les dizen muchas iniurias) and even beat (açotar) them when they did not answer their requests (Monumenta Xaveriana 1899-1900, 1:185-86; Reinders 2004, 195-96; App 2012, 91). An analogous instrumental approach has been attributed to Native Americans. Pierre de Lancre, a theorist and practitioner of witch hunting, wrote in his tract Tableau de linconstance des mauvais anges et démons (1612) (with a reference to Spanish scholar and missionary José de Acosta) that the Native Americans worshipped their Gods (i.e., demons) devoutly. If their graven images did not answer their prayers, however, they proceeded to beat them, and then fall to their knees and ask for forgiveness (De Lancre 1613, 16). This cycle, from an unanswered request to striking the idol, and from striking it to atonement, is also quite applicable to many descriptions of punishment/blackmail directed against saints by Catholics.

\section{Violence against Images: Between Belief and Unbelief}

Historians writing about punishment/blackmail directed against religious images (Richard Trexler used materials from fifteenth- to sixteenth-century Florence, Serge Gruzinski from sixteenth- to seventeenth-century colonial Mexico, Boris Uspensky and Andrei Bulychev from Muscovy in the same period, Elena Smilyanskaya from the eight-

elements of them (by depicting priests with concubines, for example); (3) erronious (erroneae) - depending on the nature of the error, they can be monstrous, apocryphal, superstitious, etc.; (4) suspect (suspectis) - when, for example, a demon in priestly vestments is baptizing an infant, the viewer might think that a baptism performed by an unsuitable priest is invalid; (5) heretical (haereticis) - when they uncritically depict objects and practices that are directly condemned by the Catholic Church (a woman performing a mass, someone wrecking sacred images, etc.). See Paleotti 1594, 146-65 (for more on punishment/blackmail - 161); Prodi 2012, 160-72.

23. For example, Michel Le Nobletz (1577-1652), one of the most active missionaries of the French Counter-Reformation, encountered the practice of beating statues of saints when preaching in western Brittany. See Verjus 1666, 184. For more on Catholic discourses associated with internal and external missionary activities in the sixteenth to seventeenth centuries, see Wanegffelen 2007, 1:259-76. 
eenth-century Russian Empire) unanimously indicate that this kind of violence against holy items and intense reverence for them are two sides of the same coin. As Trexler wrote, this violence was based on devoted "friendship." A person invests so much time, money, hope, and self-denial into an image he reveres, only to have it fail to hear him at a difficult moment. He is left disappointed and enraged that "his" Christ, "his" Virgin Mary, or "his" saint did not answer his prayer, did not come to his aid, did not rescue him from his plight, and therefore failed to meet their obligations. As such, he does not take vengeance against every Christ or Saint Anthony, but only his own, the one he "knows," the one that let him down. His Christ or Saint Anthony is indissolubly identified with a specific image and its prototype, which acts through that image to accept people's prayers and reveal its power to them (Trexler 1972, 26-29; Gruzinski 1994, 67-68).

Elena Smilyanskya describes this exact phenomenon, but does so on the basis of material from eighteenth-century Russia. According to her, despite Church sermonizing against deifying icons and prohibitions against calling them "gods," "in the consciousness of the common people, the concept of the 'Godhead' was cognized in a purely material sense, most often embodied in an icon." In 1736, soldier Phillip Mandykhin, complaining about the weather, said "yesterday, where God was, it was dry, but now it's wet; I'd like to take God [i.e., the icon M.M.] and lash him with a whip!" This lack of piety did not stem from doubts about the omnipotence of God, but rather "from the typical, everyday consciousness of the convergence of the sacred with the earthly and the transference of earthly relationships to relationships with the Most High" (Smilyanskaia 2003, 218-19). ${ }^{24}$

Nonetheless, while examining such cases, one must not forget several debatable points. Firstly, blackmail, which entails not only specific demands, but also the hope that they will be met, is sometimes indistinguishable in form from impotent threats or mere outbursts of

24. People pray to icons passionately, humiliate them, or smash them into pieces. This explosive mixture of hope and violence is sometimes presented as a unique feature of (folk) Orthodoxy, with its particular attitude toward images and "deification" of icons. Some trace this unique feature of Orthodoxy back to Byzantine theology, others to ancient Slavic paganism (Uspenskii 1982, 182, 114-15; Bulychev 2005, 167, 170, 172; see Tarasov 1995, 76). This unique feature of (folk) Orthodoxy is, however, clearly greatly exaggerated. As we shall see, analogous or even identical practices also existed in the Catholic world for centuries. The main difference was that, as far as I have been able to determine, these practices of punishment/blackmail directed against icons were never directly legitimized by the Church in medieval Russia. 
anger. ${ }^{25}$ For some people, threats directed against saints could clearly have been a kind of blasphemous flourish. For example, Count Mario Tolomeo Nerucci, who was denounced to the Spanish Inquisition in 1685, was famously fond of saying "Saint Peter, I will pull out your beard!" at the card table (Barberato 2012, 78).

Secondly, not every threat against a statue or fresco should be taken as evidence of a breach of trust or "argument" with the saint they depict. An identical gesture - (public) humiliation, damage, or destruction inflicted on the figure of a saint - could hide competing and sometimes mutually exclusive feelings. Let us consider three stories:

No. 1. In 1501, a certain Antonio Rinaldeschi was hanged in Florence. His crime was as follows: he lost at dice and despairingly threw a piece of dung at a fresco depicting the Annunciation against the backdrop of a little chapel not far from the taverna where fortune had failed him. After committing his crime, he fled, and when he was finally tracked down and facing arrest, he unsuccessfully attempted to stab himself with a knife. He was ultimately sentenced to death because he had committed several crimes (games of chances, sacrilege, and attempted suicide) and because it would serve as a warning to other evildoers. Rinaldeschi had a nasty reputation, was not known for showing any particular reverence for the Virgin Mary, and committed his act of blasphemy in a fit of anger because he lost at dice (See Konnell and Konstebl [Connell and Constable] 2010; Holmes 2013).

No 2. In 1520, a certain Uli Anders in the village of Utznach in the Canton of Zurich broke a small carved crucifix and threw it out the window. He declared that "there is no sense in idols and that they cannot help with anything." The only thing known about Anders is that he had previously laughed at a cardinal's attendant, telling witnesses that they should revere God in heaven, and not "the body of the lord," that is, he apparently attacked the Catholic doctrine of the mass. The city council of Zurich sentenced him to death for blasphemy. It is unknown if Anders had ever heard the teachings of Martin Luther and

25. Smilyanskya refers to a case involving junior clerk Vassily Gustyshev. He once got drunk with his guests, and when two soldiers appeared to summon him for his service, he flew into a rage, looked at an icon in a metal frame, and proceeded to curse. Different witnesses presented different versions of his words: "if you don't take pity on me, I'll peel you [i.e., remove you from the frame - M.M.] and throw you in a pile of shit!" or "ever since I hung you up, I've known no happiness, and if you don't take pity on me, I'll peel you and smash you to pieces!" (Smilianskaia 2003, 215). It is not always possible to draw a clear line between blackmail and cursing (especially when they clearly blend together in the speaker's own consciousness). Therefore, it is important to know whether the threat remained on the level of words or was actually translated into action. 
Ulrich Zwingli, the fathers of the Reformation, but his sacrilegious gesture was probably intended to expose the Catholic cult of images as idolatry (Wandel 2012, 485-86, 488, 495-97).

No. 3. In 1569, the wife of a tailor in Bologna named Andrea Montanari yielded to appeals from her confessor and denounced her husband to the Inquisition. According to her, whenever he was working and a thread broke, he would instantly explode with filthy blasphemy. At one point, when yet another needle failed him, he ripped a paper image of the Madonna from the wall and threw it in the fire, and then shredded and burned another paper icon depicting Christ on the cross with the Virgin Mary and Mary Magdalene nearby. He threatened that if the thread broke again, he would wipe his ass with the Virgin Mary. He also threatened that he wanted to buy [an image of] Christ and bake it in the oven like a pretzel. According to her testimony, Andrea never once went to confession or took the sacraments during the sixteen years of their marriage (Scaramella 2007, 55-70).

An ideologically motivated Protestant iconoclast breaks a Catholic crucifix or a statue of one of the saints in order to demonstrate the emptiness and powerlessness of the "idol," while a Catholic who does so is enraged by the fact that the higher powers have not helped him and he hopes to take revenge against the power contained in that image. The first strives to destroy the system at its foundation; for him, the Catholic cult of images is idolatry. The second recognizes that system and is simply angry that it did not work in his particular case. Is it not, however, those who are still not convinced of the power of the saints or the effectiveness of images who are prone to this practice of punishment?

There is certainly a boundary between a moment of vexation at a lack of help from a heavenly patron and doubts regarding their power as such, between situational non-belief in the power of one particular statue and a rejection of the cult of images, but it is sometimes fluid. After all, believing in the saints, like believing in God, simultaneously means believing that they exist and believing in them in the sense of investing one's hope in them. One can believe in the reality of heavenly patrons, but lose faith in the idea that they care for people; entertain the idea that they are benevolent toward others but lose personal hope in them; stop praying to them and decide that they do not exist; assert that they do not exist in the hope that they will make their presence felt; worship while feeling (knowing, fearing ....) that one's requests are disappearing into the void, and so on. Some individuals, such as freethinkers and religious nonconformists, attack altars and 
statues not out of hostility against particular heavenly protectors, but to go through them to settle accounts with the Church and its clergy, whose power over people is based on holy items and the redemptive practices structured around them.

\section{References}

Acta sanctorum ordinis S. Benedicti: Saeculum I. 1719. Antwerp.

Ankarloo, B., S. Clark, and W. Monter. 2002. Witchcraft and Magic in Europe: The Period of the Witch Trials. Vol. 4 of Witcheraft and Magic in Europe. London: The Athlone Press.

App, U. 2012. The Cult of Emptiness: The Western Discovery of Buddhist Thought and the Invention of Oriental Philosophy. Kyoto: UniversityMedia.

Bailey, M. D. 2009. “A Late-Medieval Crisis of Superstition?” Speculum 84 (3): 633-61.

Barberato, F. 2012. The Inquisitor in the Hat Shop: Inquisition, Forbidden Books and Unbelief in Early Modern Venice. Farnham, UK: Ashgate Publishing.

Barnum, P. H., ed. 2004. Dives and Pauper: Introduction. Vol. 2. Oxford: Oxford University Press.

Baschet, J. 2008. L’iconographie médiévale. Paris: Gallimard.

Baschet, J., and P.-O. Dittmar, eds. 2015. Les images dans l'Occident médiéval. L'atelier du médiéviste 14. Turnhout: Brepols.

Bel'ting, Kh. 2002. Obraz i kul't: Istoriia obraza do epokhi iskusstva [Image and cult: The history of the image before the era of art]. Moscow: Progress-Traditsiia.

Bodin, J. 1586. De la Demonomanie des sorciers. Anvers.

Bohier, N. 1576. Decisiones aureae in sacro Burdegalensium senatu olim discussarum. Venice.

Brunet, D. A., and D. H. Quentin, eds. 1910. Boninus Mombritius: Sanctuarium, seu vitae sanctorum; Novam hanc editionem curaverunt duo monachi Solesmenses. Paris: Fontemoing et Cie.

Bulychev, A. A. 2005. Mezhdu sviatymi i demonami: Zametki o posmertnoi sud'be opal'nykh tsaria Ivana Groznogo [Between saints and demons: Notes on the posthumous fate of the disgraced Tsar Ivan Groznyi]. Moscow: Znak.

Buñuel, L. 1985. My Last Breath. London: Flamingo.

Burns, S. P., ed. 2001. Las Siete Partidas. Vol. 5. Philadelphia: De Gruyter.

Camille, M. 1989. The Gothic Idol: Ideology and Image-Making in Medieval Art. New York: Cambridge University Press.

Canones et decreta sacrosancti oecumenici Concilii Tridentini sub Paulo III, Iulio III et Pio IV pontificibus maximis cum patrum subscriptionibus. 1856. Leipzig.

Choffari, D. 2012. "Ioann arkhidiakon: 'Historia translationis Sancti Nicolai' v srednevekovoi Evrope" ["Archdeacon John, 'Historia translationis Sancti Nicolai' in medieval Europe"]. Evraziia: Dukhovnye traditsii narodov 4: 204-16.

Christin, O. 1991. Une révolution symbolique: L'iconoclasme huguenot et la reconstruction catholique. Paris: Les Éditions de Minuit.

---. 1994. "Sur la condamnation du blasphème (XVIe-XVIIe siècles)." Revue d'histoire de l'Église de France 80 (204): 43-64.

De Certain, E., ed. 1858. Les miracles de saint Benoît. Paris. 
Durand, G. 1614. Rationale divinorum officiorum. Vol. 1. Antwerp.

Freedberg, D. 1982. "The Hidden God: Image and Interdiction in the Netherlands in the Sixteenth Century." Art History 5: 133-53.

Friedberg, A., ed. 1959. Corpus iuris canonici: Editio Lipsiensis Secunda; Pars prior Decretum magistri Gratiani. Graz: Akademische Druck- und Verlagsanstalt.

Gaztambide, J. G. 1971. "El tratado ‘de superstitionibus' de Martín de Andosilla.” Cuadernos de etnología y etnografía de Navarra 9: 249-322.

Geary, P. 1979. "L'humiliation des saints." Annales: Économies, Sociétés, Civilisations 34 (1): $27-42$.

Graesse, Th. 1850. Jacobi a Voragine Legenda aurea, vulgo Historia lombardica dicta. Leipzig: G. Koebner.

Gruzinski, S. 1994. La guerra de las imágines: De Cristóbal Colón a "Blade Runner" (14922019). Mexico: Fondo de Cultura Económica.

-_-. 1995. "Images and Cultural Mestizaje in Colonial Mexico." Poetics Today 16 (1): 53-77.

Harris, A. F. 2008. "The Performative Terms of Jewish Iconoclasm and Conversion in Two Saint Nicholas Windows at Chartres Cathedral." In Beyond the Yellow Badge: Anti-Judaism and Antisemitism in Medieval and Early Modern Visual Culture, edited by M. Merback, 119-42. Leiden: Brill.

Herolt, J. 1606. Sermones discipuli de Sanctis, cum exemplorum promptuario ac miraculis Beatae Virginis. Venice.

Holmes, M. 2013. The Miraculous Image in Renaissance Florence. New Haven, CT: Yale University Press.

Kenaan-Kedar, N. 1986. "Les modillons de Saintonge et du Poitou comme manifestation de la culture laïque." Cahiers de civilisation médiévale 29 (116): 311-30.

Konnell, U. Dzh., and Dzh. Konstebl [William J. Connell, Giles Constable]. 2010. Sviatotatstvo i vozdanianie v renessansnoi Florentsii: Delo Antonio Rinal'deski [Sacrilege and retribution in Renaissance Florence: The affair of Antonio Rinaldeschi]. Moscow: Kanon.

Lancre, P. de. 1613. Tableau de l'inconstance des mauvais anges et démons. Paris.

Lincoln, B. 1989. Discourse and the Construction of Society: Comparative Studies of Myth, Ritual, and Classification. Oxford: Oxford University Press.

Little, A. G. 1908. Liber exemplorum ad usum praedicantium saeculo XIII compositus a quodam fratre minore anglico de provincia Huberniae. Aberdeen.

Little, L. K. 1979. "La morphologie des malédictions monastiques." Annales: Économies, Sociétés, Civilisations 34 (1): 43-6o.

Lopez, G., ed. 1843. Las siete partidas del rey don Alfonso el Sabio. Vol. 4. Paris: Lecointe y Laserre.

Luard, H. R., ed. 1876. Matthaei Parisiensis, monachi Sancti Albani, Chronica majora. Vol. 3. Rerum britannicarum medii aevi scriptores 57. London: Her Majesty's Stationary Office.

Major, J. 1633. Magnum speculum exemplorum ex plusquam octoginta auctoribus. Douai.

Mansi, G. D. Sacrorum conciliorum nova et amplissima collectio. Vol. 11. Florence, 1765; Vol. 12. Florence, 1766; Vol. 24. Venice, 1780.

Martène, E. 1717. Thesaurus novus anecdotorum. Vol. 4. Paris.

Meister, A., ed. 1901. Die Fragmente Libri VIII miraculorum des Caesarius von Heisterbach. Rome.

Minin, S. A. 2009. "Kazus Gvido': Narushil li Bog dogovor s krestonostsami?” [“'Casus Guido': Did God violate his contract with the crusaders?"] Vestnik RGGU 15: 131-41. 
Miraculum sancti Carlifei ad ipsius sepulcrum facta. In Acta sanctorum ordinis sancti Benedicti. Saeculum 1. Vol. 1. Antwerp, 1719.

Molanus, J. 1570. De picturis et imaginibus sacris liber unus, tractans de vitandis circa eas abusibus ac de earundem significationibus. Louvain.

Montesano, M. 200o. "Fantasima, fantasima che di notte vai": La cultura magica nelle novelle toscane del Trecento. Roma: Città Nuova.

Monumenta Germaniae Historica: Scriptores rerum Merovingicarum. Vol. 1, 2: Gregorii Turonensis Opera, part 2: Miracula et opera minora: Editio nova lucisope expressa. 1885. Hannover.

Monumenta Xaveriana ex autographis vel ex antiquioribus collecta. 1899-190o. Vol. 1. Madrid.

Paleotti, G. 1594. De imaginibus sacris et profanis illusstriss. et reverendiss. libri quinque. Ingolstadt.

Pontano, G. 1509. De bello neapolitano et de sermone. Napoli.

Prodi, P., ed. 2012. Gabriele Paleotti: Discourse on Sacred and Profane Images. Los Angeles: Getty Research Institute.

Reinders, E. 2004. "Monkey Kings Make Havoc: Iconoclasm and Murder in the Chinese Cultural Revolution.” Religion 34 (3): 191-209.

Renversement de la morale chrétienne par les désordres du monachisme. $2 e$ partie. 1695. Amsterdam.

Sansterre, J.-M. 1999. “L’image blessée, l’image souffrante: Quelques récits de miracles entre Orient et Occident (VIe-XIIe siècle)." In Les images dans les sociétés médiévales: Pour une histoire comparée; Actes du colloque international (Rome, Academia Belgica, 19-20 juin 1998), edited by J.-M. Sansterre and J.-C. Schmitt, 113-30. Rome.

-_-. 2009. "Miracles et images: Les relations entre l'image et le prototype céleste d'après quelques récits des Xe-XIIIe siècles.” In La performance des images, edited by A. Dierkens, G. Bartholeyns, and Th. Golsenne, 47-57. Brussels: Éditions de l'université de Bruxelles.

- - . 2010. "La Vierge Marie et ces images chez Gautier de Coinci et Césaire de Heisterbach." Viator 41: 147-78.

- - . 2013. "Après les Miracles de sainte Foy: Présence des saints, images et reliques dans divers textes des espaces français et germanique du milieu du XIe au XIIIe siècle." Cahiers de civilisation médiévale 56: 39-76.

- - . 2015. "Vivantes ou comme vivantes: Lanimation miraculeuse d'images de la Vierge entre Moyen Âge et époque moderne.” Revue de l'histoire des religions 2 (232): $155-82$.

Santyves, P. 1933. "De l'immersion des idoles antiques aux baignades des statues saintes dans le christianisme." Revue de l'histoire des religions 108: 144-92.

Scaramella, P. 2007. "'Madonne violate e Christi abbruciati”: Note sull'iconoclastia in Italia tra Rinascimento e Controriforma.” In Dai cantieri alla storia: Liber amicorum per Paolo Prodi, edited by G. P. Brizzi, G. Olmi, 55-70. Bologna: CLUEB.

Schmitt, J.-C. 2005. Medioevo "superstizioso". Economica Laterza 333. Bari: Editori Laterza.

Scribner, R. 1987. Popular Culture and Popular Movements in Reformation Germany. London: The Hambledon Press.

Shmitt, J.-C. 2002. "Kul'tura imago" ["Culture of imago”]. In Annaly na rubezhe vekov: Antologiia, edited by S. I. Luchitskaia and A. Ia. Gurevich, 79-104. Moscow: XXI vek, Soglasie. 
Shprenger, Ia., and G. Institoris [Jakob Sprenger and Henricus Institoris]. 2001. Molot ved'm [The hammer of witches]. Moscow: Amfora.

Smilianskaia, E. B. 2003. Volshebniki, Bogokhul'niki, Eretiki: Narodnaia religioznost' $i$ "dukhovnye prestupleniia" $v$ Rossii XVIII $v$. [Wizards, Blasphemers, Heretics: Popular religiosity and "spiritual crimes" in Russia in the eighteenth century]. Moscow: Indrik.

Strange, J. 1851. Caesarii Heisterbacensis monachi Ordinis Cisterciensis Dialogus miraculorum. Vol. 2. Cologne.

Tarasov, O. Iu. 1995. Ikona i blagochestie: Ocherki ikonnogo dela v imperatorskoi Rossii [The icon and piety: Essays on the case of the icon in Imperial Russia]. Moscow: Progress-Kul'tura; Traditsiia.

Thibodeau, Th. M., ed. 2007. The Rationale Divinorum Officiorum of William Durand of Mende (a New Translation of the Prologue and Book One). New York: Columbia University Press.

Trexler, R. C. 1972. "Florentine Religious Experience: The Sacred Image." Studies in the Renaissance 19: 7-41.

Tubach, F. C. 1969. Index Exemplorum: A Handbook of Medieval Religious Tales. Helsinki: Suomalainen Tiedeakatemia.

Uspenskii, B. A. 1982. Filologicheskie razyskaniia $v$ oblasti slavianskikh drevnostei [Philological researches in the field of Slavic antiquities]. Moscow: Izd. Mosk. un-ta.

Van Dam, R., ed. 2004. Gregory of Tours: Glory of Confessors. Liverpool: Liverpool University Press.

Vauchez, A. 1999. "Les images saintes: Représentations iconographiques et manifestations du sacré." In Saints, prophètes et visionnaires: Le pouvoir surnaturel au Moyen Âge, 79-91. Paris: Albin Michel.

Verjus, A. 1666. La vie de M. Le Nobletz: Missionnaire de Bretagne. Paris.

Villa-Flores, J. 2006. Dangerous Speech: A Social History of Blasphemy in Colonial Mexico. Tucson: University of Arizona Press.

Voraginskii, Iakov. 2017. Zolotaia legenda [The golden legend]. Moscow: Izdatel'stvo frantsiskantsev.

Wandel, L. P. 2012. "Idolatry and Iconoclasm: Alien Religions and Reformation." In Iconoclasm and Text Destruction in the Ancient Near East and Beyond, edited by N. N. May, 485-500. Chicago: The Oriental Institute.

Wanegffelen, Th. 2007. "Acculturation ecclésiastique et 'religion populaire': Hommage à l'auteur du concept de 'profanisation." In Mélanges à la mémoire de Michel Péronnet, edited by H. Michel and J. Fouilleron, 1:259-76. Montpellier: Presses Universitaires de la Méditerranée.

Weir, A., and J. Jerman. 1999. Images of Lust: Sexual Carvings on Medieval Churches. New York: Routledge. 